\title{
ISLAND GEOGRAPHY SHAPING MARITIME SPACE IN MACARONESIA
}

\author{
Helena Maria Gregório Pina Calado ${ }^{1,2}$ (D) , Mario Caña Varona² (D) , Juan Luis Suárez de Vivero ${ }^{3}$ (D) , Fabiana \\ Cordeiro Moniz $^{2,4}$ (D) , Firdaous Halim ${ }^{5}$ (D) , Daniela de Lima Gabriel ${ }^{6}$ (D) , Cláudia Luísa Salvador Hipólito ${ }^{6}$ (D) , \\ Elisabetta Menini ${ }^{7}$ Diogo Kramel ${ }^{2}$ (D) , Marta Horta de Sousa Vergílio ${ }^{6}$ (D) , Maria Adelaide Ferreira ${ }^{1}$ (D) \\ ${ }^{1}$ MARE - Marine and Environmental Sciences Centre \\ Campo Grande, 1749-016 Lisboa: Portugal \\ helena.mg.calado@uac.pt•maferreira@fc.ul.pt \\ ${ }^{2}$ Faculty of Sciences and Technology, Department of Biology, University of the Azores \\ Mãe de Deus St., Ponta Delgada: Portugal \\ cmario1985@hotmail.com • diogo.kramel@gmail.com \\ ${ }^{3}$ Department of Human Geography, University of Seville \\ María de Padilla s/n, 41004 Seville: Spain \\ vivero@us.es \\ ${ }^{4}$ The Gaspar Frutuoso Foundation \\ Ponta Delgada Campus, 9560-801 Ponta Delgada: Portugal \\ fabiana.ic.moniz@uac.pt \\ ${ }^{5}$ Intergovernmental Oceanographic Commission of UNESCO \\ 7, place de Fontenoy, 75732 cedex 07 Paris: France \\ firdaous.halim@gmail.com \\ ${ }^{6} \mathrm{CIBIO}$ - Research Center in Biodiversity and Genetic Resources / InBIO - Associate Laboratory, University \\ of the Azores \\ Rua da Mãe de Deus, 13-A, 9501-801 Ponta Delgada: Portugal \\ daniela.l.gabriel@uac.pt • claudia.Is.lopes@uac.pt• marta.hs.vergilio@uac.pt \\ ${ }^{7}$ Nicholas School of the Environment, Duke University \\ 9 Circuit Drive, NC 27708, Durham: USA \\ elisabetta.menini@duke.edu
}

\begin{abstract}
This paper explores how geography shapes human uses of the maritime space along the Atlantic archipelagic territories of Macaronesia, a biogeographical region that includes the archipelagos of the Azores, Madeira, Selvagens, Canary Islands and Cape Verde. The way specific geographic characteristics of these islands influence and even determine maritime uses and activities is analyzed in a three-layers approach in the following order: socio-economic analysis, sectorial analysis and uses and activities analysis. The biophysical and geographical characteristics of each archipelago will be considered throughout the analysis, highlighting the common aspects and peculiarities between each region. After a comprehensive overview of the main economic activities, the discussion suggests that certain specificities need to be taken into account in maritime spatial planning processes when planning and managing human uses at sea, to promote the sustainable development of local communities, particularly in archipelagic regions.
\end{abstract}

Keywords: archipelagic regions, island geography, maritime uses. 


\section{Introduction}

The ocean embraces many populated islands and archipelagic countries and territories, with such a diverse mix of traits and characteristics that make each one unique. However, despite their particular differences or specificities, insular territories and the human populations therein have in common a strong link and dependence on the ocean and its resources, as major sources of sustenance, income, and cultural identity (Vince, Brierley, Stevenson \& Dunstan, 2017; Greenhill, 2018).

Insularity, often linked to remoteness, poses many challenges to islanders, including limited land-based resources (including space available for infrastructure), ecological fragility and vulnerability to economic and/or environmental forcing factors, potential over exploitation of local resources, sea level rise and other impacts of climate (and environmental) change (such as pollution) (Greenhill, 2018). Demography, quite often translating into small and/or declining populations, is a particular challenge due to small domestic markets and potentially limited 'social capital' (Greenhill, 2018). Furthermore, the geographic characteristics of most islands or archipelagic territories are a key factor determining the use of surrounding maritime space by human populations, including aspects such as geology, topography, bathymetry, exposure to winds and waves, and geographic location, which further influences and shapes local climate.

These information assist the maritime spatial planning (MSP) process by increasing the overall understanding of the natural characteristics of the maritime space, from which human uses will essentially derive from. Essentially, most economic activities on sea rely upon at least one biophysical asset or upon the geographical context of the region. Altogether, they are subsidy in order to carry out a sustainable MSP process. In this sense, Zaucha (2012) lists relevant information that should be acquired, such as hydrological, biological and geomorphological processes, the coexistence of different sea uses and the intensity of their interactions, among others.

This paper explores how geography shapes human uses of the maritime space along the Atlantic archipelagic territories of Macaronesia, a biogeographical region including the archipelagos of the Azores, Madeira, Selvagens, Canary Islands and Cape Verde (Fernandez-Palacios et al., 2011). The way specific geographic characteristics of these islands influence and even determine maritime uses and activities is analyzed, as well as how these specificities need to be taken into account in MSP processes when planning and managing human uses at sea.

\section{Geobiophysical characterization of Macaronesia}

The term Macaronesia (Gr. Makarios, blissful + nessos, islands), coined circa 1835, is attributed to English botanist Phillip Barker Webb (Fernandez-Palacios et al., 2011) to describe the region that encompasses the Atlantic archipelagos of the Azores, Madeira, Selvagens, Canary Islands and Cape Verde (Fig. 1, Tables 1 and 2).

These archipelagos share similar geomorphological traits. They are all originally volcanic and are thought to be the result of several geologic hotspots (Carracedo, 2001). Topography and geomorphology varies within Macaronesia, with an array of landscapes ranging from deserts in arid and rocky areas to humid mountains and evergreen broadleaf forests; from low lying to mountainous islands with altitudes reaching over 2000 meters; and from very steep cliff areas to lower plateaus with numerous gorges. The islands also present prominent river valleys in eroded volcanic 
rocks as well as vast lava flows and active volcanoes (Condé et al., 2009).

Macaronesia has a unique biogeography. All native flora and fauna is believed to have reached the archipelagos via long-distance dispersal from adjacent continental areas (Whittaker \& Fernández-Palacios, 2007) or adjacent archipelagos (Domingues et al., 2008). Although the marine biotas of the different archipelagos are interconnected via oceanic currents, they belong to different marine provinces: while the Azores, Madeira and Canary Islands belong to the Lusitanian province in the Temperate Northern Atlantic Realm, Cape Verde is within the West African Transition province

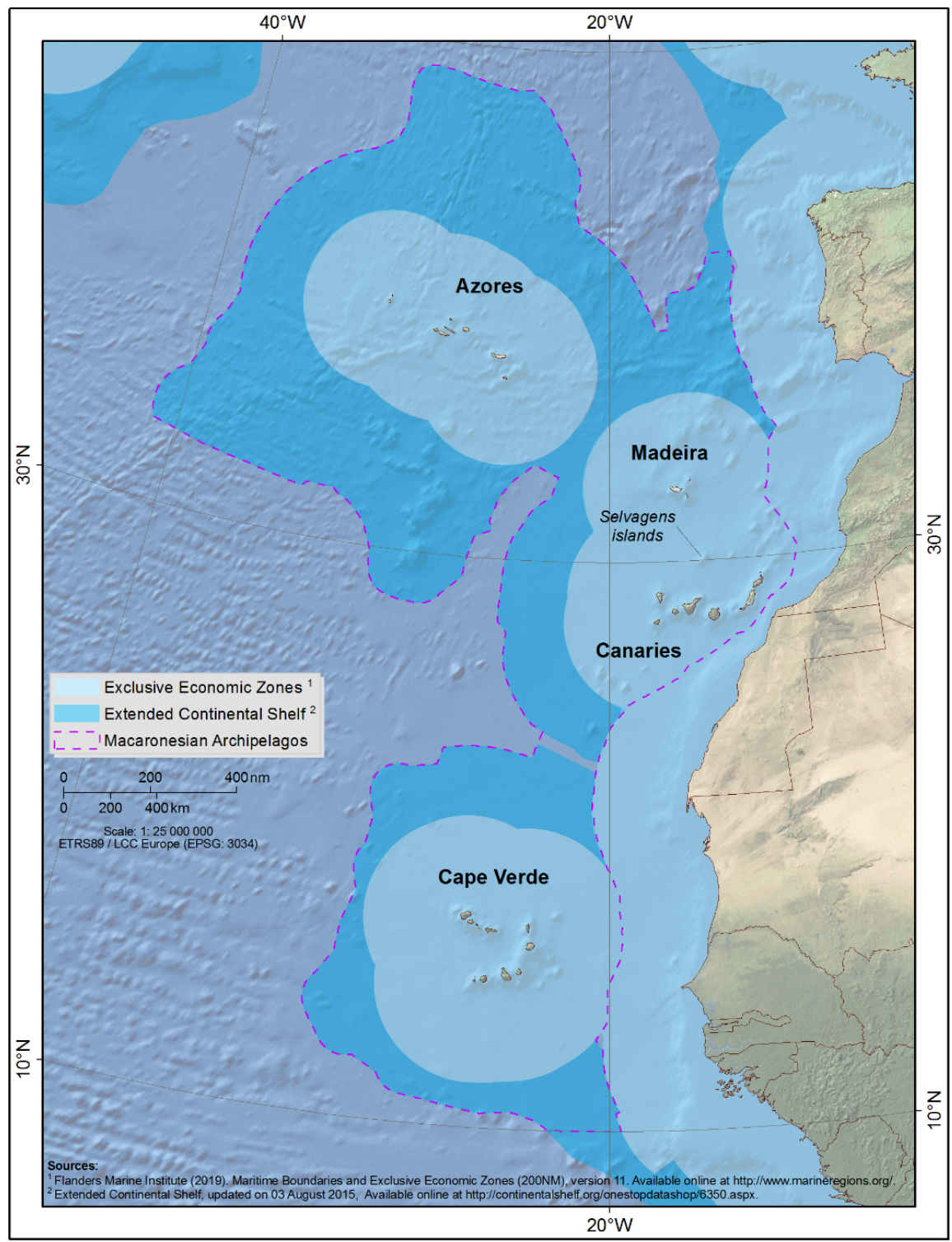

Figure 1. Macaronesia region and archipelagos Source: authors' own elaboration. 
in the Tropical Atlantic Realm (Spalding et al., 2007; Tuya \& Haroun 2009).

The Portuguese archipelago of the Azores is located along the Mid Atlantic Ridge on three tectonic plates: European, African and American. It is composed of 9 islands divided in three groups totaling $2322 \mathrm{~km}^{2}$. The Azores is the most isolated archipelago of Macaronesia. The island of São Miguel is located $1369 \mathrm{~km}$ west of mainland Portugal and the island of Corvo is located $1900 \mathrm{~km}$ east of Canada (Newfoundland). The archipelago is characterized by high average depths (1000$2000 \mathrm{~m}$ ) between its islands except for Faial and Pico islands that are separated by 20 to $50 \mathrm{~m}$ depths (Azevedo, Macedo \& Mendonça, 2016; Interreg, 2017).

The Portuguese archipelago of Madeira lies on the African Plate, circa $660 \mathrm{~km}$ west of Morocco. It is the smallest archipelago of European Macaronesia ( $802 \mathrm{~km}^{2}$ of land surface). It includes two main islands, Madeira and Porto Santo, and the uninhabited Desertas Islands (Chão, Deserta Grande and Bugio).

The Selvagens archipelago comprises two subarchipelagos: a northeast group that includes Selvagem Grande, a plateau $100 \mathrm{~m}$ above the ocean surface with plunging cliffs (Quartin Graça, 2013) and three small islets (da Terra, do Mar and Sinho), and a southwest group with Selvagem Pequena and eight islets (de Fora, Alto, Comprido, Redondo, Pequeno, Grande, do Sul and do Norte). The archipelago has a total land area of $3.6 \mathrm{~km}^{2}$. Due to its narrow continental shelf, the

Table 1. Geographic parameters of the Macaronesia Archipelagos

\begin{tabular}{|c|c|c|c|c|c|}
\hline Parameters & Azores & Madeira & Canary Islands & Cape Verde & Macaronesia \\
\hline Country & Portugal (EU) & Portugal (EU) & Spain (EU) & Cape Verde (AU) & Europe - Africa \\
\hline $\begin{array}{l}\text { Distance from national } \\
\text { capital }(\mathrm{km})\end{array}$ & 1548 & 1041 & 1850 & - & - \\
\hline $\mathrm{N}^{\circ}$ of main islands & 9 & 2 & 7 & 10 & 28 \\
\hline $\begin{array}{l}\text { Number of } \\
\text { municipalities }\end{array}$ & 19 & 11 & 87 & 14 & \\
\hline Length of coastline $(\mathrm{km})$ & 943 & 418 & 1482 & 979 & \\
\hline Land surface $\left(\mathrm{km}^{2}\right)$ & 2322 & 802 & 7447 & 4033 & 14604 \\
\hline $\begin{array}{l}\text { Exclusive economic } \\
\text { zone-EEZ }\left(\mathrm{km}^{2}\right)\end{array}$ & 955644 & 454459 & 455328 & 796555 & 2661986 \\
\hline $\begin{array}{l}\text { Extended continental } \\
\text { shelf - ECS }\left(\mathrm{km}^{2}\right)\end{array}$ & \multicolumn{2}{|c|}{2115100} & 298800 & 5382 & 15051 \\
\hline Maximum elevation (m) & $\begin{array}{l}2351 \\
\text { (Pico) }\end{array}$ & $\begin{array}{c}1862 \\
\text { (Madeira) }\end{array}$ & $\begin{array}{c}3718 \\
\text { (Tenerife) }\end{array}$ & $\begin{array}{c}2829 \\
\text { (Fogo) }\end{array}$ & $\begin{array}{c}3718 \\
\text { (Tenerife) }\end{array}$ \\
\hline $\begin{array}{l}\text { Age of oldest island } \\
\text { (My) }\end{array}$ & $\begin{array}{l}8 \text { (Santa } \\
\text { Maria) }\end{array}$ & $\begin{array}{c}14 \\
\text { (Porto Santo) }\end{array}$ & $\begin{array}{c}21 \\
\text { (Fuerteventura) }\end{array}$ & $\begin{array}{c}28 \\
\text { (Sal) }\end{array}$ & $\begin{array}{c}28 \\
\text { (Sal) }\end{array}$ \\
\hline Latitude $\left({ }^{\circ}\right)$ & $37-39 N$ & $33 \mathrm{~N}$ & $27-29 N$ & $16-24 N$ & $16-39 N$ \\
\hline Longitude $\left({ }^{\circ}\right)$ & $20-31 W$ & $15-17 W$ & $13-18 W$ & $21-26 W$ & $13-31 W$ \\
\hline Colonization date & $1432 \mathrm{AD}$ & $1420 \mathrm{AD}$ & ca. $2500 \mathrm{BP}$ & $1462 \mathrm{AD}$ & - \\
\hline Population & 245283 & 256424 & 2101924 & 491875 & 3095506 \\
\hline
\end{tabular}

Source: authors' own elaboration based on MAC (2004), Suárez de Vivero and Rodrigues Mateos (2007), Ramalho (2011), EP (2014), INECV (2015), Azevedo et al. (2016), DREM (2016), ISTAC (2016), Madruga et al. (2016), INECV (2017), SREA (2018) and SAU (2019). 
Table 2. Island dimensions of Macaronesia

\begin{tabular}{|c|c|c|c|}
\hline Region/Group & Island & Area $\left(\mathrm{km}^{2}\right)$ & Length of coastline $(\mathrm{km})$ \\
\hline \multicolumn{4}{|c|}{ Autonomous Region of Azores } \\
\hline \multirow{2}{*}{ Eastern Group } & Santa Maria & 96.89 & 78.00 \\
\hline & São Miguel & 744.57 & 230.00 \\
\hline \multirow{5}{*}{ Central Group } & Terceira & 400.27 & 126.00 \\
\hline & Graciosa & 60.66 & 44.00 \\
\hline & São Jorge & 243.65 & 139.00 \\
\hline & Pico & 444.80 & 153.00 \\
\hline & Faial & 173.06 & 80.00 \\
\hline \multirow{2}{*}{ Western Group } & Flores & 140.96 & 72.00 \\
\hline & Corvo & 17.11 & 21.00 \\
\hline \multicolumn{4}{|c|}{ Autonomous Region of Madeira } \\
\hline Madeira & - & 758.50 & 311.00 \\
\hline Porto Santo & - & 43.01 & 107.00 \\
\hline Selvagem Grande & - & \multirow{2}{*}{3.60} & - \\
\hline Selvagem Pequena & - & & - \\
\hline \multicolumn{4}{|c|}{ Canary Islands } \\
\hline \multirow[t]{4}{*}{ Province of Santa Cruz de Tenerife } & El Hierro & 268.71 & 41.05 \\
\hline & La Gomera & 369.76 & 97.45 \\
\hline & La Palma & 708.32 & 155.55 \\
\hline & Tenerife & 2034.38 & 358.00 \\
\hline \multirow{3}{*}{$\begin{array}{l}\text { Province of Las Palmas de Gran } \\
\text { Canaria }\end{array}$} & Fuerteventura & 1659.74 & 339.82 \\
\hline & Gran Canaria & 1560.10 & 242.95 \\
\hline & Lanzarote & 845.94 & 247.49 \\
\hline \multicolumn{4}{|c|}{ Republic of Cabo Verde } \\
\hline \multirow{4}{*}{ Leeward } & Maio & 269.00 & 79.00 \\
\hline & Santiago & 991.00 & 172.00 \\
\hline & Fogo & 476.00 & 82.00 \\
\hline & Brava & 64.00 & 43.00 \\
\hline \multirow{6}{*}{ Windward } & Santo Antão & 779.00 & 134.00 \\
\hline & São Vicente & 227.00 & 85.00 \\
\hline & Santa Luzia & 35.00 & 33.00 \\
\hline & São Nicolau & 343.00 & 138.00 \\
\hline & Sal & 216.00 & 91.00 \\
\hline & Boa Vista & 620.00 & 122.00 \\
\hline
\end{tabular}

Source: authors' own elaboration based on Duarte (2013), INECV (2015), DREM (2016), ISTAC (2016) and SREA (2018).

surrounding sea is very deep, mostly between $3500-4000 \mathrm{~m}$ with a maximum depth of $5400 \mathrm{~m}$ (Interreg, 2017). The archipelago is integrated in the Autonomous region of Madeira, and because of its particular features (very small land area and limited resources), it is only inhabited by a very small permanent population of park rangers and occasional visitors (Quartin Graça, 2013).

The Canary Islands is the biggest archipelago of Macaronesia $\left(7447 \mathrm{~km}^{2}\right)$ and the closest to the African continent (Fuerteventura Island is located $96 \mathrm{~km}$ west of Western Sahara). It is composed by two provinces and seven main islands (Madruga, Wallenstein \& Azevedo, 2016). Steep slopes plunging to $1000 \mathrm{~m}$ depths define the seafloor bathymetry around the archipelago. The deepest waters are located in the western part, while in the eastern areas depths do not exceed 2500 me- 
ters (Suárez de Vivero, 2011; Interreg, 2017).

The Republic of Cape Verde is an African archipelagic nation located $570 \mathrm{~km}$ off the coasts of Senegal at the same latitude of the promontory Cape Verde from which it received its name (Ramalho, 2011). It is the only territory of Macaronesia not included in the European Union. It is the second largest archipelago in Macaronesia $\left(4033 \mathrm{~km}^{2}\right)$ and it is formed by 10 main islands and eight minor islets. Rising from a dome-shaped ocean floor, the average depth below sea level is around 3000 meters (Duarte, 2013).

\section{Methodology}

The present study aims to analyse and provide insights in how the geographical characteristics in the Macaronesia influences the uses and activities and furthermore the MSP process. Therefore, an analysis of the main geographical features and the most relevant uses and activities are reviewed according to the methodology shown in Figure 2, ensuring that all sectors and characteristics are addressed in this analysis.

This analysis can be understood in three stages. First, an overall economic analysis is conducted to understand the economic context of each archipelago. Second, the importance of each sector (primary, secondary, tertiary) will be analysed in terms of what uses and activities are more prominent economically and culturally for each archipelago. Last, each of the uses and activities (the nine sectors of blue economy) will be addressed individually in terms of the main challenges for the proper implementation of MSP and Ecosystem Based Management (EBM) in the islands.

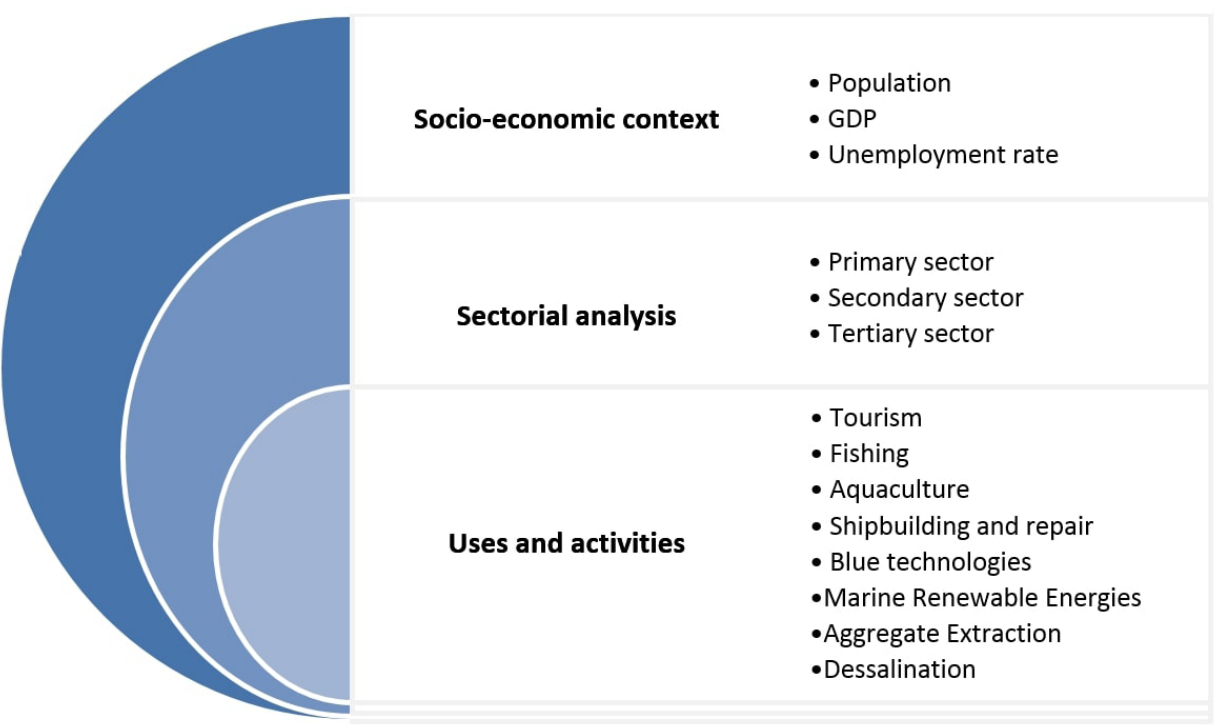

Figure 2. Methodology implemented in the study Source: authors' own elaboration. 


\section{Results}

\section{Socio-economic context of Macaronesia}

More than three million people inhabit Macaronesia. The Canary Islands is the most populated archipelago with a total population surpassing two million inhabitants. The Canary Islands and Madeira have the highest population densities (circa 300 inhabitants $/ \mathrm{km}^{2}$ ), while the Azores is the least populated archipelago (approximately 250000 inhabitants) and has the lowest population density (106 inhabitants/ $\mathrm{km}^{2}$ ) (Table 3).

The population is heterogeneously distributed among the islands of each archipelago, concentrating in a few islands: $56 \%$ of the Azorean population lives in São Miguel, $55 \%$ of the population of Cape Verde lives in the island of Santiago, and $41 \%$ of the population of the Canary Islands lives in Grand Canary Island. This high concentration in the main islands creates some social issues, along with immigration and high unemployment rates.

The standard of living in the islands (Gross Domestic Product - GDP per capita) varies significantly between European Macaronesia and Cape Verde. GDP per capita in the three EU archipelagos is over $€ 15000$, but below the EU average of $€ 29121$ (EC, 2018a). Cape Verde has the lowest GDP per capita in Macaronesia (€3000), but, conversely, it has the lowest unemployment rate (10.7\% in 2010) (Nshimyumuremyi, 2018). The Canary Islands have the highest unemployment rate $(29.1 \%)$, affecting especially women and young people (less than 25 years old). This figure has improved in recent years, but it is still above the national Spanish and EU average of $18.6 \%$ and $8.1 \%$, respectively (EC, 2018a). Madeira and the Azores had a severe increase in their unemployment rates in the years following the global economic crisis.

Table 3. Socioeconomics of the Macaronesian Archipelago (*2014 data; **2015 data)

\begin{tabular}{|l|c|c|c|c|}
\hline \multicolumn{1}{|c|}{ Island } & $\begin{array}{c}\text { Total } \\
\text { population }\end{array}$ & $\begin{array}{c}\text { Population density } \\
\text { (inhabitants } / \mathrm{km}^{2} \text { ) }\end{array}$ & GDP per capita $(€)^{*}$ & $\begin{array}{c}\text { Unemployment rate } \\
(\%)^{* *}\end{array}$ \\
\hline Azores & 246353 & 106 & 15111 & 12.8 \\
\hline Madeira & 258686 & 323 & 15710 & 14.7 \\
\hline Canary Islands & 2104815 & 283 & 19581 & 29.1 \\
\hline Cape Verde & 524833 & 130 & 3065 & 12.4 \\
\hline
\end{tabular}

Source: authors' own elaboration based on Madruga et al. (2016) and INECV (2017).

\section{Sectorial analysis of the Macaronesia economy}

The primary sector is not very developed and declining in Macaronesia due to the rugged topography, climatic factors, and water scarcity. These factors limit the space available for agriculture, the average size of farms, their access and mechanization. Nevertheless, small-scale subsistence agriculture production is present in Cape Verde, Madeira, and Canary Islands. Contrariwise, in the Azores, agriculture is one of the mainstays of the economy, which, along with fisheries, contributes with $10 \%$ of Gross Value Added (GVA).

The secondary sector remains generally undeveloped and is dominated by traditional industries, mainly food, beverages, and tobacco. It faces difficulties linked to low internal demand, the remoteness of the archipelagos and their dependence on external supply that increases produc- 
tion costs compared to the mainland. The construction industry is subject to difficulties as well as it is dependent on the evolution of other sectors, and on raw material shortage.

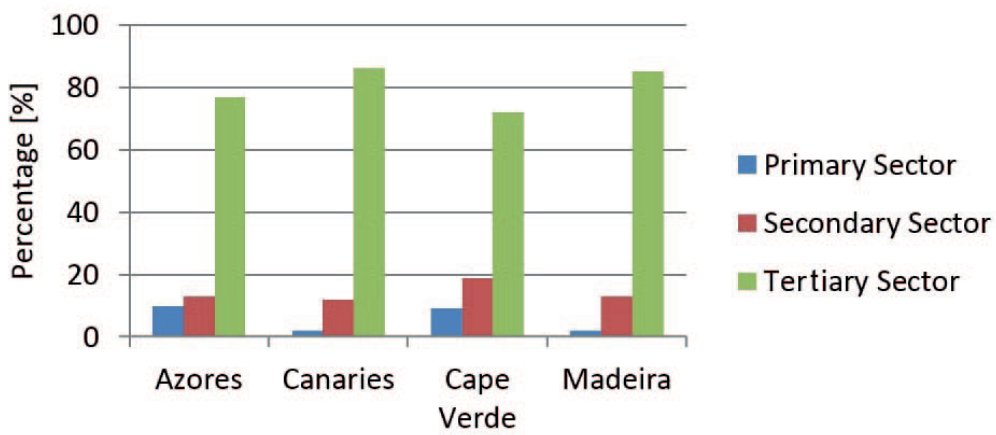

Figure 3. Percentage contribution of economic sectors to the GVA of Macaronesian archipelagos Source: authors' own elaboration based on CVSY (2015) and Madruga et al. (2016).

The economy in Macaronesia is, however, service-oriented. The tertiary sector accounts for more than $70 \%$ of total GVA in all archipelagos of Macaronesia (Fig. 3). The main contributor is the tourism sector, which has been thriving during the last decades in the four archipelagos as a source of income.

A more comprehensive analysis of each sector for each island is shown in Table 4, in which they are organized in primary, secondary and tertiary sector, highlighting the main economic activities.

\section{Main aspects of blue economy development in Macaronesia}

Tourism thrives in the various archipelagos of Macaronesia mostly because of their particular natural and environmental characteristics, including agreeable weather, rugged and sometimes unexplored natural landscapes, unique ecosystems, and biodiversity, including endemic species and abundance of submarine life. Cultural aspects are also relevant, such as hospitality, and more specific facets of the archipelagos such as aspects of cultural diversity (e.g. Cape Verde), unique cultural landscapes (e.g. 'levadas', unique hiking trails in Madeira).

The sector thrives especially in the Canary Islands (over thirteen million visitors in 2016) and Madeira (over one million visitors in 2016), where tourism specialization goes back to the end of the $19^{\text {th }}$ century (Matos, 2002). The Azores is the only archipelago worldwide to have earned the Sustainable Tourism Destination Certificate, awarded by the Global Sustainable Tourism Council (Paiva, 2019).

Fishing is an ancestral practice in Macaronesia and remains mostly artisanal (mostly small scale vessels up to $12 \mathrm{~m}$ in length). The activity is severely limited by natural/oceanographic conditions in some of the archipelagos. In the Azores, despite the large size (area and volume) of the archipelago's marine waters, fisheries can potentially only use $2.2 \%$ of its total area up to a depth of 1000 meters, due to the absence of a continental shelf and to high average depths throughout the archipelago. These physical aspects account for a relative lack of biomass and biologically frailty, especially regarding demersal and deep-water species (EC, 2017). In Madeira, extremely deep with low productivity waters and the narrow continental shelf also limit available habitats for coastal 
Table 4. Macaronesian economy

\begin{tabular}{|c|c|c|c|}
\hline Archipelago & Primary sector & Secondary sector & Tertiary sector \\
\hline Azores & $\begin{array}{l}\text { Agriculture: Main productions including livestock } \\
\text { and dairy production (> } 100000 \text { ha of available } \\
\text { farmland, and circa } 25 \% \text { of the Portuguese milk } \\
\text { production) (Madruga et al., 2016). } \\
\text { Fisheries: essential economic activity with average } \\
\text { annual revenue circa } € 35 \text { million (Madruga et al., } \\
2016) \text {. } \\
\text { Main catches: tuna, swordfish, blue jack mackerel, } \\
\text { conger, crustaceans (lobsters), mollusks (EC, 2017). } \\
\text { The most significant proportion of catches is by } \\
\text { vessels }<12 \text { m. } \\
\text { Generate circa } 500 \text { direct jobs (fishers, haulers and } \\
\text { support staff on land). Sector faces problems of } \\
\text { overexploitation and limitations under agreements } \\
\text { with third countries. } \\
\text { Aquaculture: being promoted as an alternative to } \\
\text { fisheries. }\end{array}$ & $\begin{array}{l}\text { Mainly based on the production of } \\
\text { dairy products (milk, cheese) and } \\
\text { transformation of fisheries products, } \\
\text { such as tuna: fisheries generate circa } \\
1000 \text { indirect jobs, in the fish marketing } \\
\text { circuit (maritime and air transport), and } \\
\text { in the processing industry (preserves), } \\
\text { concentrated in units producing canned } \\
\text { tuna, for exportation. }\end{array}$ & $\begin{array}{l}\text { Tourism: the industry has been progressively gaining weight } \\
\text { in the archipelago because of its particular natural/envi- } \\
\text { ronmental characteristics (weather, natural landscapes, } \\
\text { ecosystems, biodiversity), and contributing to the economy, } \\
\text { employability, and internationalization of the archipelago. } \\
\text { Infrastructure has grown exponentially in recent years, near- } \\
\text { ing } 14000 \text { tourism beds in } 2016 \text {; overnight stays increased } \\
\text { from circa } 569000 \text { in } 2011 \text { to } 974600 \text { in } 2016 \text {. Total revenue } \\
\text { increased from } € 48 \text { million in } 2011 \text { to over } € 87 \text { million in } \\
2017 \text { (SREA, 2018). The archipelago is well connected to } \\
\text { mainland Europe. Several air companies (including low } \\
\text { costs) offer direct connections and tour packages from Eu- } \\
\text { rope and North America, i.a. (Calado, Borges, Ng \& Vergílio, } \\
2017 \text { ). }\end{array}$ \\
\hline Madeira & $\begin{array}{l}\text { In } 2014 \text { accounted for } 2 \% \text { of the GVA (Table } 2 \text { ). } \\
\text { Agriculture: grounded on sugar cane, vines, and } \\
\text { bananas. Some temperate and tropical fruits are } \\
\text { cultivated for export. } \\
\text { Fisheries: predominantly artisanal, contribute to } \\
\text { only } 0.71 \% \text { of the GDP and to } 0.64 \% \text { of employ- } \\
\text { ment (Vallerani, Marti \& Ojamaa, 2017). Main } \\
\text { catches: tuna, black scabbardfish (EC, 2017). }\end{array}$ & $\begin{array}{l}\text { Industry relates mostly to the produc- } \\
\text { tion of artisanal goods (e.g. embroider- } \\
\text { ies). Advanced financial services and } \\
\text { favorable fiscal conditions offered by } \\
\text { the archipelago attract many interna- } \\
\text { tional finance companies (EC, 2018b). }\end{array}$ & $\begin{array}{l}\text { Tourism: } 85 \% \text { of the GVA and } 75 \% \text { of employed popula- } \\
\text { tion. Tourism offer focuses on the natural and cultural } \\
\text { environment (natural landscapes and unique hiking trails), } \\
\text { high-quality hotels, tax breaks and accessibility. Infrastruc- } \\
\text { ture ( } 2016) \text { : } 265 \text { hotels ( } 12 \% \text { of which with } 5 \text {-star facilities) } \\
\text { and a total capacity of } 35177 \text { tourism beds (capacity to } \\
\text { accommodate }>1 \text { million tourists a year). Most tourism } \\
\text { development is concentrated around the main city, Funchal } \\
\text { (53\% of all hotels, } 66 \% \text { of rooms and of total lodging capac- } \\
\text { ity). The archipelago is well connected by air to } 30 \text { different } \\
\text { main European cities (Almeida \& Correia, 2010). }\end{array}$ \\
\hline
\end{tabular}




\begin{tabular}{|c|c|c|c|}
\hline Canary Islands & $\begin{array}{l}\text { In } 2014 \text { accounted for } 2 \% \text { of GVA (compared to } \\
30 \% \text { in the 1960s) (Madruga et al., 2016). } \\
\text { Agriculture: Currently, only } 10 \% \text { of the archipel- } \\
\text { ago's } \\
\text { surface is farmed mainly with dryland } \\
\text { cultures, and a small portion of irrigation } \\
\text { farming (bananas, tomatoes), for the Spanish } \\
\text { and European markets, and other crops also } \\
\text { for export, mainly tropical fruits and flowers. } \\
\text { Fisheries: Despite a narrow continental shelf } \\
\text { and relatively poor waters, reached over } 18055 \\
\text { tons, and €46.99 million in } 2011 \text { (Popescu et } \\
\text { al., 2013). Circa } 87 \% \text { of fishing fleet is artisanal } \\
\text { with diverse fishing gears. Remaining vessels } \\
\text { include trawlers, longlines and purse seiners. } \\
\text { Main catches: Atlantic chub mackerel, sardinellas, } \\
\text { skipjack tuna, parrotfish, and yellow } \\
\text { fin tuna. }\end{array}$ & $\begin{array}{l}\text { Industry and construction sectors are } \\
\text { responsible for } 7.9 \% \text { and } 5 \% \text { of the total } \\
\text { GVA, respectively (EC, 2018a), and do } \\
\text { not have a significant impact on the } \\
\text { economy of the archipelago. } \\
\text { Fish processing: the activity has almost } \\
\text { disappeared in the archipelago; consists } \\
\text { mainly of processing fresh and frozen } \\
\text { fish for distribution, freezing and } \\
\text { production } \\
\text { of cured and smoked fish. }\end{array}$ & $\begin{array}{l}\text { Tourism: with circa } 12 \text { million visitors a year, the sector } \\
\text { accounts for } 86 \% \text { of the economy in the archipelago and } \\
\text { employs } 87 \% \text { of the population (Madruga et al., 2016). } \\
\text { Infrastructure } \\
\text { (2016): }>2000 \text { hotels and total lodging capacity } \\
\text { of circa } 422500 \text { tourism beds. }\end{array}$ \\
\hline Cape Verde & $\begin{array}{l}\text { Employs nearly } 40 \% \text { of the population, but } \\
\text { contributes only } 9 \% \text { to the GVA. } \\
\text { Agriculture: negatively affected by arid climate } \\
\text { and droughts. Cape Verde imports nearly } 90 \% \\
\text { of its food and material needs (over } 60 \% \text { of the } \\
\text { country's GDP) (Nshimyumuremyi, 2018). } \\
\text { Fisheries: remain small-scale and artisanal in } \\
\text { spite of a vast EEZ and the enormous potential } \\
\text { of its marine resources (Nshimyumuremyi, } \\
2018 \text { ). Main catches: fish and shellfish of high } \\
\text { commercial value (exported fresh, frozen and } \\
\text { canned). }\end{array}$ & $\begin{array}{l}\text { Industry is limited to light manufac- } \\
\text { turing } \\
\text { and accounts for only } 3.4 \% \text { of the GDP. } \\
\text { Main industries: food industry and } \\
\text { manufacture of furniture and mat- } \\
\text { tresses } \\
\text { account for } 45 \% \text { of industries in } 2013 \\
\text { (INECV, 2015). In 2017, construction } \\
\text { represented } \\
8.4 \% \text { of GDP. Exports include } \\
\text { fuels, lubricants, and fish (Nshimyu- } \\
\text { muremyi, } \\
2018 \text { ). }\end{array}$ & $\begin{array}{l}\text { Tourism (and foreign direct investment in the sector): } \\
\text { approximately } \\
70 \% \text { of GDP in } 2016 \text { (Nshimyumuremyi, 2018). } \\
\text { Activity takes advantage of various natural aspects (climate, } \\
\text { sand beaches, abundance of submarine life and rugged and } \\
\text { unexplored landscapes), culture (hospitality, significant } \\
\text { cultural } \\
\text { diversity), and favourable political environment (democratic } \\
\text { stability) (Lopez-Guzman, Borges \& Cerezo, 2011). } \\
\text { Average growth of } 11.4 \% \text { /y between } 2000-2010 \text {, higher } \\
\text { than the growth rates of world tourism (Ribeiro, Valle \& } \\
\text { Silva, } 2013 \text { ). Number of tourists doubled between } 2010 \text { and } \\
2016 \text { (from circa } 382000 \text { to } 644500 \text { ), as did overnight stays, } \\
\text { from } 2.3 \text { to } 4 \text { million (INE, 2017). Infrastructure (2016): } 233 \\
\text { hotels and lodging capacity of }>18000 \text { tourism beds, } 46.2 \% \\
\text { of which in Sal island (INE, 2017). } \\
\text { Most of the country's trade is with the European Union, } \\
\text { with } 85 \% \text { of total exports of goods, and over } 95 \% \text { of exports } \\
\text { of services (tourism) (Nshimyumuremyi, 2018). The majority } \\
\text { of tourists (60\%) visiting the country do it on charter flights } \\
\text { mostly to the islands of Sal and Boa Vista (Ribeiro et al., } \\
2013 \text { ). } \\
\text { Cruise tourism: growing rapidly in recent years (approxi- } \\
\text { mately } \\
50000 \text { tourists in 2012) (Ribeiro et al., 2013). }\end{array}$ \\
\hline
\end{tabular}


and demersal species and fishing methods. In the Canary Islands, despite the existence of a narrow continental shelf and relatively poor waters, fishing is still an important activity. The reduction of outermost regions' fleets and fleet capacities to maintain sustainable fishing stocks, has contributed to a decreasing trend in the number of vessels and fishers (EC, 2017). Cape Verde has a vast EEZ and the enormous potential of its marine resources and fishing is an important branch of the economy, and one of the leading export sectors (Nshimyumuremyi, 2018). In 2008, the sector employed 10500 people (61\% of which in harvesting). In relative terms, the Cape Verdean processing industry is the most important in Macaronesia.

Although marine aquaculture is being promoted in the Azores as an alternative to fisheries, natural (physical and oceanographic) and weather conditions in the archipelago are generally not favorable to the installation of the activity. Contrarily, in Madeira, due to much more favorable environmental conditions, marine aquaculture has a high potential, even if it still has a low economic weight.

In the Canary Islands, aquaculture production totaled 7648 tons in 2015, with a value at first sale of $€ 34$ million (EC, 2017). The activity is almost entirely based on sea bass and sea bream reared in sea cages. In 2011, the sector started to produce microalgae, Senegalese sole and shrimp.

Since the $19^{\text {th }}$ century, the strategic position of Macaronesian archipelagos around the midpoint of the Atlantic trading routes made them attractive as way stations between Europe and the rest of the world. They were used for resupplying water, fresh goods, and coal to steamships (Bosa, 2013). The situation has not changed since then, and the islands are still considered as a convergence of shipping lanes where no significant commercial activity is taking place except in the Canary Islands (Fig. 4). In fact, compared to the other archipelagos, the Canary Islands present a high rate of maritime carriage of goods due to its growing population and to its extreme dependence on maritime transportation from mainland Europe to supply goods in order to meet local demands. The port of Las Palmas (Gran Canaria) is one of the major shipping ports in Spain. It is ranked $87^{\text {th }}$ in the top 200 ports worldwide and is an important trans-shipment point on international shipping routes (Tovar, Hernandez \& Rodriguez-Deniz, 2015). It stands out in terms of fuel supplies, passenger traffic and container traffic with a total transaction of nearly $1.1 \mathrm{mln}$ TEUs in 2010 (Camarero Orive et al., 2016).

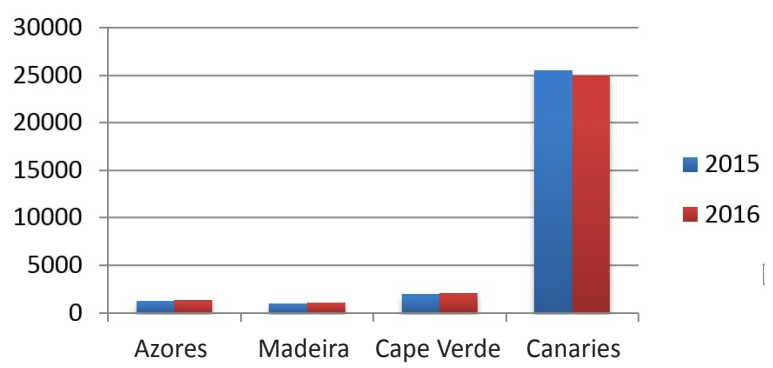

Figure 4. Maritime freight transport (1000 tonnes) in the Macaronesian archipelagos in 2015 and 2016 Source: authors' own elaboration based on Eurostat (2018), SREA (2018) and INECV (2015). 
Shipbuilding and repair are marginal activities in Macaronesia. In the Azores, shipbuilding consists of the construction of fishing vessels, while ship repair, mostly of fishing vessels and recreational boats, is in decline. Considering the potential increase of yachting and sailing boats calling for services in Azores, vessel repair could represent an important development possibility. In Madeira, ship repair is concentrated in Funchal, with a number of companies involved in the repair of engines, electric and electronic parts and mechanical repairs. Its development is linked to the increase in yachts and sailing boats calling in at the islands and to the management of spaces in port areas. In the Canary Islands, shipbuilding and repair is in decline. Revision, repair and maintenance of oil platforms of the Gulf of Guinea have contributed to reactivate the activity over the last five years, but the drop in oil barrel prices has slowed down the growth of the sector. The growth of nautical activities, such as fitting out and repair of nautical craft, offers further opportunities for the reactivation of the sector (EC, 2017).

Blue biotechnology is currently only relevant in the archipelago of Madeira and the Canary Islands, but there is potential interest in exploring biological organisms from extreme environments (such as hydrothermal vents) found in the Azores archipelago (Gianni, Ferreira, Boschen-Rose \& Johnson, 2019). In Madeira, a public-private partnership (university-micro company) is producing natural extracts obtained from marine macroalgae. In the island of Porto Santo, a small plant is producing biofuel from microalgae (EC, 2017). In the Canary Islands, microalgae production is in place as a branch of aquaculture.

Azores (specifically, Pico Island) has one of the first wave energy plants in the world, a collaborative pilot project designed and developed by three universities (Instituto Superior Técnico, mainland Portugal; Queen's University of Belfast and the University College Cork, Ireland). However, the existence of technical problems and the minute amounts of energy produced so far, still do not allow wave energy to be considered as a promising activity for the short to medium term.

In the Canary Islands, the natural oceanographic conditions of the archipelago offer the potential for becoming an international laboratory for the testing of new blue energy developments, namely through PLOCAN (Plataforma Oceanográfica de Canarias - Oceanographic Platform of the Canary Islands) and the regional government has been requesting from the national Spanish government the recognition of competences in relation to marine renewable energies (EC, 2017).

In Macaronesia, aggregate extraction occurs only in the Azores and Madeira, consisting, respectively, of sand extraction, and of gravel and sand extraction. In both cases the activity has limited economic relevance, employs few people, and does not offer good prospects due to the decline of demand and high investments required to carry out the activity (EC, 2017).

Deep-sea mining can be considered as a particular aspect of aggregate extraction. There is interest on the exploration and potential exploitation of polymetallic sulphides, formed by hydrothermal vent systems along the Mid Atlantic Ridge, where the Azores archipelago is located (Gianni et al., 2019).

In Macaronesia, this activity, whose development is receiving international support, is carried out almost entirely in the Canary Islands, which is among the world leaders in the desalination of seawater with 320 desalination plants. The activity has been one of the main factors allowing tourism development in archipelago, but consumes large amounts of electricity obtained from fossil fuels, with the associated environmental impacts and substantial costs. Experiences are ongoing in the archipelago to use on-land wind energy in desalination plants (EC, 2017). In the archipelago of Madeira, there is one plant in the island of Porto Santo, which seems sufficient to satisfy local demand. The activity is also being developed in Cape Verde. No official data are available on the number of plants currently operated in the Cape Verdean archipelago. 


\section{Discussion and conclusions}

The main economic activities in Macaronesia are strongly reliant on the specificities of the various archipelagos. This study analyzed particularly the geographical and biophysical influences on the main uses and activities, which are also affected by climate and cultural characteristics, included to some extent.

Tourism is the main economic activity and takes advantage of the unique natural and cultural settings of each one of the archipelagos, coupled to the remoteness and exotic feel of some of these destinations. In Cape Verde, projections for the service sector in 2018 are optimistic and include a considerable increase in private investment in tourism. However, boosting tourism and generating more substantial economic benefits in Cape Verde will require structural reforms, such as better organization of the local production of goods and services, the creation of a quality certification system for local products, and improvements in inter-island transportation (Nshimyumuremyi, 2018).

Despite the vastness of the maritime territories of these archipelagos, fishing in Macaronesia is hampered by very narrow (in some cases, virtually non-existent) continental shelves, and low productivity waters, which significantly limit the activity. In the case of the Azores, sometimes rough ocean conditions further deter seafaring activities. Aquaculture constitutes an alternative source of seafood protein, but again, due to physical (oceanographic) limitations, only in the Canary Islands and, to some degree, in Madeira. Macaronesian archipelagos have traditionally been important stopovers along transatlantic shipping routes, and remain important as such. The Canary Islands rank the highest in Macaronesia in terms of freight cargo and also cruise tourism, while the latter is also extremely important for the archipelago of Madeira, growing rapidly in Cape Verde and, also, to some extent, in the Azores, where yachting is an important activity. Conversely, shipbuilding and repair are mostly in regression. Blue biotechnology is only currently relevant in two of the archipelagos (Madeira and Canary Islands) but has great potential for development in the Azores, due to the ongoing search for biochemical material from extreme environments such as the ones found in hydrothermal vents along the Mid-Atlantic Ridge where the Azores are located. Marine renewable energies, while of great interest to secure an independent/autonomous energy supply of these islands, are, as in the case of fisheries and aquaculture, also limited by the physical (bathymetric and oceanographic) conditions of the archipelagos, with plunging cliffs and/or very narrow continental shelves. Aggregate extraction, consisting mostly of sand and gravel extraction in the Azores and Madeira, currently has limited economic impact. Again, the particular physical characteristics of the different archipelagos may play a key role in the near future in the development of this activity, particularly in what concerns the exploration and exploitation of polymetallic sulphides in the Azores, where these aggregates are formed in association with hydrothermal vent systems. Lastly, desalination of seawater for the production of drinking water for human consumption is a reality in the more meridional archipelagos in Macaronesia (Madeira, Canary Islands, Cape Verde), again because of their particular, in this case, (more) arid climates. The Azores, because of their central Atlantic location enjoys a more humid climate than the rest of the archipelagos in Macaronesia.

It becomes clear that island geography shapes the use of the various maritime spaces in Macaronesia in many and diversified ways. It may act sometimes as a restricting condition to the full developing of an activity, not providing the feasible means or not enabling profitable margins, and at the same times those conditions may be allow and foster other uses and activities. Recognizing these specificities is key to plan and manage the use of each of these maritime spaces sustainably, 
namely in the framework of MSP initiatives. Also, the scales and strategies of MSP should differ according to jurisdictional maritime areas with the first miles around the islands having detail scales and zoning, while the large EEZ and ECS being subject to more strategic planning. It is also crucial to comprehend how each sector and activity can be addressed within the Blue Growth policy, in terms of very well established activities (coastal and maritime tourism) and potential ones (aquaculture and biotechnology). Furthermore, it is cornerstone to understand the geographical and biophysical conditions within this context in order to capitalizing them in favor of the environmental and economic sustainability in archipelagic regions while developing their MSP projects. MSP is mandatory in the EU through Directive 2014/89/EU, and is the ocean management regime advocated by the United Nations for coastal and marine waters worldwide.

In the Archipelagos of the Macaronesia, MSP is being addressed by each national government at different stages of development, as well as in the scope of the MarSP (Macaronesian Maritime Spatial Planning) project that includes all the archipelagos except Cape Verde. The MarSP is a twoyear long project, ending in 2019 that aims to reinforce MSP by assisting the competent authorities of Portugal and Spain and to provide management tools that are adapted to the regional environmental and socio-economic settings of each archipelago. By recognizing the specificities dictated by the particular geographies of the various archipelagos and islands, MSP in the Macaronesia can contribute to further the sustainable development of human communities and uses at sea.

\section{Acknowledgements}

This work is a contribution to the GPS Azores - Geographical and Political Scenarios and Maritime Spatial Planning for the Azores and North Atlantic (Ref. ACORES-01-0145-FEDER-00002 GPS Azores) financed in $85 \%$ by FEDER and in $15 \%$ with regional funds by structural funds through the Azores 2020 Operational Programme.

The authors are grateful to Christine Ladiero for her contribution with statistics and to Sarah Mahadeo for her assistance in editing and language check.

\section{References}

Almeida, A., \& Correia, A. (2010). Tourism development in Madeira: an analysis based on the life cycle approach. Tourism Economics, 16(2), 427-441. Retrieved from https://doi. org/10.5367/000000010791305644

Azevedo, J., Macedo, F., \& Mendonça, E. (2016). Macaronesia Regional Investment Strategy. BEST: Voluntary Scheme for Biodiversity and Ecosystem Services in Territories of European Overseas. Fundo Regional da Ciência e Tecnologia Governo dos Açores. European Commission. Retrieved on November 15, 2019 from https://www.azores.gov.pt/NR/rdonlyres/F25135CF-528F-45BC-AC0475532410BDE5/1051238/RISMacaronesia_14Dec2016vJA.pdf

Bosa, M. S. (2013). The Control of Port Services by International Companies in the Macaronesian Islands (1850-1914). In J., Curry-Machado (Ed.). Global Histories, Imperial Commodities, Local Interactions (pp. 58-76). London: Palgrave Macmillan. Retrieved from https://doi.org/10.1057/9781137283603_4

CVSY (2015). Cabo Verde Statistical Yearbook 2015. Instituto Nacional de Estatística. Retrieved on July 11, 2018 from http://ine.cv/wp-content/uploads/2017/02/statistical-yearbook-cv-2015_en.pdf

Calado, H., Borges, P., Ng, K., \& Vergílio, M. (2017). Case Study Portugal: Addressing tourism development and climate change in small Atlantic islands: the case of the Azores. In A., Jones, \& M., Phillips (Eds.). Global Climate Change and Coastal Tourism: Recognizing Problems, Managing Solutions and Future Expectations (pp. 125-137). Wallingford: CABI. Retrieved from https://doi. org/10.1079/9781780648439.0125 
Camarero Orive, A., Cerbán Jiménez, M., Turias Domínguez, I., González Cancelas, N., \& Camarero Orive, A. (2016). Metodología para la clasificación de los puertos mediante indicadores de explotación utilizando análisis de conglomerados. INGE CUC, 12(2), 41-49. Retrieved from https://doi.org/10.17981/ ingecuc.12.2.2016.04

Carracedo, J. C. (2001). Volcanismo reciente y riesgo volcánico. In J. M., Fernandez-Palacios, \& J., Martín (Eds.). Naturaleza de las Islas Canarias. Ecología y conservación (pp. 65-76). Santa Cruz de Tenerife: Turquesa.

Condé, S., Richard, D., Liamine, N., Leclère, A. S., Sotolargo, B., \& Pinborg, U. (2009). Biogeographical regions in Europe. The Macaronesian region - volcanic islands in the ocean. Luxembourg: European Environment Agency. Retrieved from http://ec.europa.eu/environment/nature/info/pubs/docs/ biogeos/Macaronesian.pdf

CSP (2019). Continental Shelf Programme. Retrieved from http://continentalshelf.org/onestopdatashop/6350.aspx

Domingues, V. S., Alexandrou, M., Almada, V. C., Robertson, D. R., Brito, A., Santos, R. S., \& Bernardi, G. (2008). Tropical fishes in a temperate sea: evolution of the wrasse Thalassoma pavo and the parrotfish Sparisoma cretense in the Mediterranean and the adjacent Macaronesian and Cape Verde Archipelagos. Marine Biology, 154(3), 1432-1793.

DREM (2016). Direção Regional de Estatística da Madeira. Retrieved from https://estatistica.madeira. gov.pt/

Duarte, G. B. B. (2013). Ordenamento costeiro em territórios insulares. Recomendações para o processo em Cabo Verde. Lisboa: Tese de mestrado apresentado no Instituto SuperiorTécnico para obtenção do grau de mestre em urbanismo e ordenamento do território.

EC (2017). Realising the potential of the Outermost Regions for sustainable blue growth. Final Report. European Commission - Executive Agency for Small and Medium-sized Enterprises. Retrieved from http://ec.europa.eu/regional_policy/sources/policy/themes/outermost-regions/pdf/rup_2017/ rup_sust_blue_growth_en.pdf

EC (2018a). Regional Innovation Monitor Plus Canary Island: Socioeconomic profile. European Commission. Retrieved from https://ec.europa.eu/growth/tools-databases/regional-innovation-monitor/ base-profile/canary-islands

EC (2018b). Regional Innovation Monitor Plus Madeira Region: Socioeconomic profile. European Commission. Retrieved from https://ec.europa.eu/growth/tools-databases/regional-innovation-monitor/base-profile/madeira-region

EP (2014). Optimising the potential of outermost regions. European Parliament resolution of 26 February 2014 on optimising the potential of outermost regions by creating synergies between the Structural Funds and other European Union Programmes, 2013/2178(INI)

Eurostat (2018). Eurostat - Your key to European statistics. Retrieved from https://ec.europa.eu/eurostat/web/main/home

Fernandez-Palacios, J. M., de Nascimento, L., Otto, R., Delgado, J. D., García del Rey, E., Arévalo, J. R., \& Whittaker, R. J. (2011). A reconstruction of Palaeo-Macaronesia, with particular reference to the long-term biogeography of the Atlantic island laurel forests. Journal of Biogeography, 38(2), 226246. Retrieved from https://doi.org/10.1111/j.1365-2699.2010.02427.x

Gianni, M., Ferreira, M. A., Boschen-Rose, R., \& Johnson, D. (2019). Industry reactions to ATLAS recommendations. Deliverable 7.5 of the EU ATLAS project. Retrieved from https://www.eu-atlas.org/ resources/atlas-library\#deliverables

Greenhill (2018). Marine Spatial Planning for Islands. Workshop Report. Las Palmas de Gran Canaria: S.Pro, Ecorys, Thetis, University of Liverpool, NIMRD "Grigore Antipa".

INE (2017). Instituto Nacional de Estatística Estatísticas do Turismo - Ano 2016. Retrieved from http:// ine.cv/wp-content/uploads/2017/03/turismo_2016_rev1.pdf

INECV (2015). Cabo Verde Statistical Yearbook 2015. Instituto Nacional de Estatistica de Cabo Verde. Retrieved from http://ine.cv/wp-content/uploads/2017/02/statistical-yearbook-cv-2015_en.pdf

INECV (2017). Instituto Nacional de Estatística de Cabo Verde. Retrieved from http://ine.cv/ 
Interreg (2017). Programa de Coperación Madeira-Açores-Canarias (MAC) 2014-2020. Cooperacion Territorial. Interreg, Fondo Europeo de Desarrollo Regional. Retrieved on July 4, 2017 from https:// www.mac-interreg.org/

ISTAC (2016). Insituto Canario de Estadística. Retrieved from https://www.gobiernodecanarias.org/istac/

Lopez-Guzman, T., Borges, O., \& Cerezo, J. M. (2011). Community-based tourism and local socio-economic development: A case study in Cape Verde. African Journal of Business Management, 5(5), 1608-1617. https://doi.org/10.5897/AJBM10.429

MAC (2004). Programa de Coperación Madeira-Açores-Canarias (MAC) 2014-2020. RegioPlus Consulting. Diagnóstico Territorial y Analysis DAFO del espacio de cooperación MAC. Retrieved from http:// www.pct-mac.org/FCKeditor/UserFiles/File/PROGRAMA\%202014-2020/Diagnostico\%20Territorial\%20MAC.pdf

Madruga, L., Wallenstein, F., \& Azevedo, J. M. N. (2016). Regional ecosystem profile - Macaronesian Region. EU Outermost Regions and Overseas Countries and Territories. Fundo Regional para a Ciência e Tecnologia. Retrieved from https://ec.europa.eu/environment/nature/biodiversity/best/pdf/ best-ecosystem_profile_macaronesia_2016.pdf

Matos, R. (2002). Naturalistes, malades, tourists: la naissance du tourisme à Tenerife, îles Canaries, 1850-1914. Le Globe. Revue genevoise de géographie, 142(1), 113-135. Retrieved from https://doi. org/10.3406/globe.2002.1455

Nshimyumuremyi, A. (2018). African Economic Outlook Country Note, Cabo Verde. Retrieved on July 19, 2018 from https://www.afdb.org/fileadmin/uploads/afdb/Documents/Generic-Documents/country_notes/Cabo_Verde_country_note.pdf

Paiva, R. P. (2019, December 5). Açores são o primeiro arquipélago do mundo com certificado de destino turístico sustentável. Público. Retrieved from https://www.publico.pt/2019/12/05/fugas/noticia/ acores-sao-arquipelago-mundo-certificado-destino-turistico-sustentavel-1896317

Popescu, I., Ortega Gras, J. J. (2013). Fisheries in the Canary Islands. Policy Department B: Structural and Cohesion Policies. European Parliament. Retrieved from http://www.europarl.europa.eu/RegData/ etudes/note/join/2013/495852/IPOL-PECH_NT(2013)495852_EN.pdf

Quartin Graça, J. (2013). A importância das ilhas no quadro das políticas e do direito do mar - o caso das Selvagens. Ph.D. thesis. Lisbon: Instituto Universitário de Lisboa.

Ramalho, R. A. S. (2011). Building the Cape Verde Islands. Berlin, Heidelberg: Springer-Verlag.

Ribeiro, M. A., Valle, P. O. D., \& Silva, J. A. (2013). Residents' attitudes towards tourism development in Cape Verde Islands. Tourism Geographies, 15(4), 654-679. Retrieved from https://doi.org/10.1080/ 14616688.2013.769022

SAU (2019). Sea Around Us. Retrieved from http://www.seaaroundus.org/data/\#/eez

Spalding, M. D., Fox, H. E., Allen, G. R., Davidson, N., Ferdana, Z. A., Finlayson, M. A. X., Halpern, B. S., Jorge, M. A., Lombana, A. L., Lourie, S. A., \& Martin, K. D. (2007). Marine ecoregions of the world: a bioregionalization of coastal and shelf areas. BioScience, 57(7), 573-583.

SREA (2018). Statistic Series 2011-2017. Statistics by subject - Tourism. Retrieved from https://srea. azores.gov.pt/Conteudos/Relatorios/lista_relatorios.aspx?idc=29\&idsc=1123\&lang_id=2

Suárez de Vivero, J. L. (2011). An Atlas of Maritime Spatial Planning. Marine Plan. Retrieved on October 15, 2017 from http://www.marineplan.es/en/ATLAS_13_06_11_EN.pdf

Suárez de Vivero, J. L., \& Rodriguez Mateos, J. C. (2007). Atlas of the European Seas and Oceans. Marine Jurisdictions, Sea Uses and Governance. Retrieved on July 3, 2017 from http://www.marineplan.es/ ES/ATLAS_EUROPA.pdf

Tovar, B., Hernandez, R., \& Rodriguez-Deniz, H. (2015). Container port competitiveness and connectivity: The Canary Islands main ports case. Transport Policy, 38, 40-51. Retrieved from https://doi. org/10.1016/j.tranpol.2014.11.001

Tuya, F., \& Haroun, R. J. (2009). Phytogeography of Lusitanian Macaronesia: biogeographic affinities in species richness and assemblage composition. European Journal of Phycology, 44(3), 405-413. Retrieved from https://doi.org/10.1080/09670260902836246 
Vallerani, M., Martí, C. P., \& Ojamaa, P. (2017). Research for PECH Committee - Fisheries in Madeira. Policy Department for Structural and Cohesion Policies. Retrieved on July 15, 2018 from http://www. europarl.europa.eu/RegData/etudes/IDAN/2017/601978/IPOL_IDA(2017)601978_EN.pdf

Vince, J., Brierley, E., Stevenson, S., \& Dunstan, P. (2017). Ocean governance in the South Pacific region: Progress and plans for action. Marine Policy, 79, 40-45. Retrieved from https://doi.org/10.1016/j. marpol.2017.02.007

Whittaker, R. J., \& Fernández-Palacios, J. M. (2007). Island Biogeography. Ecology, Evolution and Conservation. London: Oxford University Press.

Zaucha, J. (2012). Offshore spatial information - maritime spatial planning in Poland. Regional Studies, 46(4), 459-473. Retrieved from https://doi.org/10.1080/00343404.2012.668615 